\title{
CORRESPONDENCE
}

transcriptase activity was tested under different conditions used by mammalian retroviruses, including those previously reported by Gallo and colleagues for HTLV. Reversetranscriptase activity was indeed detected under the conditions described for HTLV-1, but that was certainly not sufficient to conclude that we were dealing with an HTLV-like virus.

The second issue raised by Montagnier concerns the cytopathic effect induced by the first HIV BRU isolate. It is true that this first isolate, as we learned later, was not a highly replicative syncitium-inducing virus. However, we know now that HIVinduced cell death is not only mediated by gp120, but is much more complex, involving multiple pathways for HIV replication. It is also true, as stated by Montagnier and mentioned in my commentary, that the first typical cytopathic effect was observed with HIV-1 LAI.

It is not surprising that 20 years after the identification of the AIDS virus, none of the contributors to this discovery has exactly the same memory of the early events. The details of the early days of AIDS research are probably not so importantthe rapid identification of the AIDS virus in the early 1980s and all the subsequent progress made by us and others were a wonderful example of integrated research.
We should keep that example in mind as we continue research on new strategies to prevent infection and to treat people living with HIV/AIDS, especially in resource-poor countries. I believe we can all agree on this common goal.

Françoise Barré-Sinoussi

Institut Pasteur, Unite de Biologie des

Retrovirus, 2526 Rue du Docteur Roux, Cedex

15, Paris, France.

e-mail: fbarré@pasteur.fr

1. Barré-Sinoussi, F. Nat. Med. 9, 844-846 (2003).

2. Montagnier, L. Virus 46-69 (W.W. Norton, London, 2000).

3. Montagnier, L. Science 298, 1727-1728 (2002).

4. Dauguet, C. Nat. Med. 9, 845 (2003).

5. Barré-Sinoussi, F. et al.Science 220, 868-871(1983).

\section{Rethinking natural-born killers}

\section{To the editor:}

The News feature on phytotherapeutic compounds sold as dietary supplements ${ }^{1}$ rightly criticizes the lax control on these products by the US Food and Drug Administration, but it goes too far when it suggests that they should be banned altogether. If such criteria were to be applied to the majority of pharmaceutical drugs presently approved, rarely would a medicine escape from being banned, including those sold over the counter. What we need is rational regulation, forcing manufacturers to clearly state side effects, dose-limited toxicity and drug interactions.

One of the phytotherapies cited in the article, for instance, was Gingko biloba. In spite of the increased risk of hemorrhage when the herb is taken indiscriminately (especially by patients submitted to surgery), several studies have shown the real benefits of Gingko biloba extracts in protecting DNA against both endogenous damage and chemical adducts-including those derived from environmental pollutants, accidental exposure to radioactivity or radiation therapy ${ }^{2,3}$.

In addition, patients with ocular and neurological degenerative disorders, hyperthermic brain injury, cerebral ischemia and vascular atherogenesis can also benefit from administration of Gingko biloba extracts ${ }^{4-7}$. One group has shown that $40 \mathrm{mg}$ of Gingko biloba extract 761, taken orally three times a day for 2 months, reduced levels of DNA-damaging metabolites to those of the control group in 30 Chernobyl 'liquidators'-the technicians, workers and engineers sent to seal the plant after the Chernobyl disaster. After treatment, the protective effect lasted for 7 months, indicating that the extract need only be taken for a short time.

Yes, we should do more research on many of these 'dietary supplements', but we should also take a look at the already-published material worldwide. The Food and Drug Administration's criteria for common drugs sold over the counter should, in the short term, be applied to supplements in order to provide an informed orientation for users. On the other hand, the literature of the past decade indicates that these products deserve to be examined for both their potential benefits and dangers. After all, even aspirin can be harmful if misused.

\section{Sandra Galeotti}

Revista da Sociedade Brasileira de Cancerologia, Rua Republica do Togo, 360 05537-110 Sao Paulo-SP, Brazil e-mail:galeotti@terra.com.br

1. Mandavilli, A. Nat. Med. 9, 634-635 (2003).

2. Emerit, I. et al. Radiat. Res. 144, 198-205 (1995).

3. Emerit, I et al. J. Cancer Res. Clin. Oncol. 120, 558-561 (1994).

4. Thiagarajan, G. et al. Eye Experim. Res. 75, 421-430 (2002)

5. Drago, F. et al. J. Ocul. Pharmacol. Ther. 2, 197-202 (2002).

6. Kobayashi, M.S. et al. Free Radic. Res. 2, 115-124 (2000).

7. Fosslien, E. Clin. Lab. Sci. 1, 25-67 (2001). 